УДК 81-115:811.111”06

DOI https://doi.org/10.26661/2414-1135-2021-83-10

\title{
КОГНІТИВНА КОРПУСНА ЛІНГВІСТИКА: СУЧАСНИЙ СТАН І ПЕРСПЕКТИВИ
}

\author{
Ділай I. П. \\ кандидат філологічних наук, доцент, \\ дочент кафедри англійської філології \\ Львівський національний університет \\ вул. Університетська, 1, Львів, Україна \\ orcid.org/0000-0001-9626-290X \\ iryna.dilay@lnu.edu.ua \\ Ділай М. П. \\ кандидат філологічних наук, дочент, \\ дочент кафедри прикладної лінгвістики \\ Національний університет «Львівська політехніка» \\ вул. Степана Бандери, 12, Львів, Україна \\ orcid.org/0000-0001-5182-9220 \\ mariannadilai@gmail.com
}

\begin{abstract}
Ключові слова: когнітивна лінгвістика, корпусна лінгвістика, когнітивнокорпусний лінгвістичний підхід, теоріі, базовані на вживанні, прикладо-базовані теоріі, корпусо-базована методологія, корпусо-керована методологія, поведінковий профіль, мультимодальний кopnyc.
\end{abstract}

У статті розглянуто особливості сучасного когнітивно-корпусного лінгвістичного підходу та подано огляд напрямів досліджень і тенденцій його застосування на прикладі англійської мови. В останні десятиліття спостерігається тенденція до синергії когнітивно-лінгвістичних теорій і корпусно-лінгвістичної методології. 3 одного боку, сучасні дослідження 3 когнітивної лінгвістики використовують корпусні дані як потужну емпіричну базу, а корпусну методологію, зокрема корпусо-базовану, для підтвердження когнітивних гіпотез. 3 іншого боку, корпусна лінгвістика не може обійтися без інтроспекції, інтуїтивних суджень про мову представників когнітивної лінгвістики. Як наслідок, з'являється низка теорій і методик, які намагаються оптимально поєднати переваги обох. У руслі когнітивної лінгвістики з'являються базовані за вживанні теорії мови, які звертаються до корпусного матеріалу, зокрема даних про частотність уживання, задля вивчення когнітивних репрезентацій. Сюди належить прикладо-базована теорія мовного знання та репрезентації (Р. Ленекер, Дж. Тейлор). Течією, яка намагається поєднати когнітивну й корпусну лінгвістики, є граматика патернів С. Ганстон і Дж. Френсіс. Стрімкого розвитку набула когнітивна корпусна семантика (Д. Герертс, Г. Шмід, Д. Дів'як, С. Грайс). Корпуси актуальні для вивчення основних проблем когнітивної семантики, зокрема концептуальної метафори, полісемії, синонімії, прототипів, аналізуконструкційтощо.Одним ізпопулярних напрямів дослідження $\epsilon$ вивчення концептуальної метафори із застосуванням корпусобазованої методології (Р. Гіббс, А. Стефанович). Корпусо-базовані методи використовуються також у дослідженні прототипів (Дж. Байбі, М. Стаббс). Поняття лексичного праймінгу передбачає, що корпусний конкорданс $\epsilon$ своєрідною моделлю ментального конкордансу. Корпусо-керована когнітивна семантика застосовується передусім для аналізу полісемії та синонімії (Д. Глинн, Дж. Ньюман, Б. Аткінс, Д. Шьонефельд). Зокрема, запропоновано підхід поведінкових профілів - керованих даними семантичних описів, які застосовують до вивчення полісемії й синонімії (П. Генкс).

Перспективним видається застосування мультимодальних корпусів, які інтегрують відео й аудіовиміри та дають можливість дослідити «ситуативне» мовне вживання (В. Еванс, М. Грін). 


\title{
COGNITIVE CORPUS LINGUISTICS: THE CURRENT STATE AND PROSPECTS
}

\author{
Dilai I. P. \\ Candidate of Philological Sciences, Associate Professor, \\ Associate Professor at the Department of English Philology \\ Ivan Franko National University of Lviv \\ Universytetska str., 1, Lviv, Ukraine \\ orcid.org/0000-0003-1165-2206 \\ iryna.dilay@lnu.edu.ua \\ Dilai M. P. \\ Candidate of Philological Sciences, Associate Professor, \\ Associate Professor at the Linguistics Department \\ Lviv Polytechnic National University \\ S. Bandera str., 12, Lviv, Ukraine \\ orcid.org/0000-0001-5182-9220 \\ mariannadilai@gmail.com
}

Key words: cognitive linguistics, corpus linguistics, cognitive corpus linguistic approach, usage-based theories, exemplarbased theories, corpus-based methodology, corpus-driven methodology, behavioral profile, multimodal corpus.
The paper presents the key ideas of the current cognitive corpus linguistic approach and provides an overview of research areas and trends in its application within the English language study. In recent decades, the synergy of cognitive linguistic theories and corpus linguistic methodology has been observed. On the one hand, modern cognitive linguistics uses corpus data as a powerful empirical basis, and corpus methodology, in particular corpusbased, to confirm cognitive hypotheses. On the other hand, corpus linguistics cannot do without introspection, intuitive judgments about the language by representatives of cognitive linguistics. As a result, a number of theories and techniques emerge that attempt to combine the benefits of both.

In line with cognitive linguistics, usage-based theories of language appear, which refer to corpus data, in particular the frequency of use, to study cognitive representations. They include an exemplar-based theory of language knowledge and representation (R. Langacker, J. Taylor). Another theory that tries to combine cognitive and corpus linguistics is the grammar of the patterns of S. Hunston and G. Francis.

Cognitive corpus semantics (D. Geeraerts, H. Schmid, D. Divjak, S. Gries) is developing rapidly. Corpora are relevant for studying the main problems of cognitive semantics, in particular conceptual metaphor, polysemy, synonymy, prototypes, constructional analysis, etc. The study of conceptual metaphor with the application of corpus-based methodology is one of the popular research areas (R.Gibbs, A. Stefanowitsch). In addition, corpus-based methods are used in prototype research (J. Bybee, M. Stubbs). The concept of lexical priming implies that corpus concordance is a kind of mental concordance model. Corpus-driven cognitive semantics is used primarily for the analysis of polysemy and synonymy (D. Glynn, J. Newman, B. Atkins, D. Schönefeld). In particular, the behavioral profiles approach based on data-driven semantic descriptions was proposed for the study of polysemy and synonymy (P. Hanks). The application of multimodal corpora, which integrate video and audio dimensions and make it possible to explore the "situated" language use (V. Evans, M. Green), seems promising. 
Постановка проблеми. Новим підходом у руслі когнітивністики $є$ когнітивна корпусна лінгвістика [1-4]. Когнітивна лінгвістика напрям лінгвістики, який сформувався в руслі когнітивної науки та вивчає співвідношення когнітивних і мовних структур, зв'язок мови та мислення [5, с. 3]. Корпусна лінгвістика - методологія, яка уможливлює «вивчення мови на основі прикладів «реального» мовного вживання» [6]. 3 початку 2000-х років у межах когнітивної лінгвістики спостерігається зміна методологічної парадигми [7]. Фокус досліджень змістився на тестування різних теорій про те, як «працює мова» [8]. На перший план виходять аналітичні корпусні методи, які базуються на кількісних даних. Синергія когнітивно-лінгвістичної теорії та корпусної методології виявляється в поступовому утвердженні нового когнітивно-корпусного лінгвістичного підходу.

Мета статті - здійснити огляд теоретико-методологічних передумов і напрямів досліджень, які грунтуються на синергії когнітивної та корпусної лінгвістики.

Мета передбачає розгляд таких завдань: 1) визначити переваги та перспективи залучення когнітивно-лінгвістичної теорії в корпуснолінгвістичні дослідження; 2) визначити переваги та перспективи залучення корпуснолінгвістичної методології в когнітивно-лінгвістичні дослідження; 3) проаналізувати напрями та приклади досліджень, виконаних у руслі когнітивної корпусної лінгвістики.

Об'єктом дослідження є когнітивно-корпусний підхід до дослідження мовних явищ.

Предмет аналізу - синергія когнітивно-лінгвістичної теорії та корпусної методології в сучасних лінгвістичних дослідженнях.

Виклад основного матеріалу дослідження. В останні десятиліття корпусна лінгвістика як методологія має найшвидші темпи розвитку в лінгвістиці, більше того, корпусна лінгвістика стає ключовою методологією в гуманітарних i соціальних науках $[9$, с. 3]. Завдання корпусної лінгвістики можна згрупувати в три основні напрями: корпусний дизайн (створення корпусу), корпусний пошук/корпусна обробка даних, статистичний аналіз [9]. Використання масивних електронних репозитаріїв автентичних анотованих текстів дає можливість значно об'єктивізувати когнітивно-лінгвістичні дослідження. Зокрема, цьому сприяє застосування корпусо-базованого підходу, метою якого $є$ знайти емпіричне підтвердження лінгвістичним гіпотезам, підібрати відповідні приклади з величезної бази даних, статистично обробити мовні дані. 3 іншого боку, корпусні дані не можуть бути адекватно розтлумачені без інтуїтивних суджень лінгвістів про мову [3, с. 7].
Синергія когнітивної та корпусної лінгвістики зумовлює поєднання якісного та кількісного аспектів дослідження. 3 одного боку, корпусна методологія підкріплює емпіричну базу когнітивної лінгвістики як теорії, яка перебуває в пошуках оптимальної методології. 3 іншого боку, корпусна лінгвістика, поєднана 3 когнітивною теорією, виходить на межі інструменталізму, статистичного аналізу до концептуального осмислення корпусних даних, вивчення ментального лексикону як ідеальної репрезентативної та збалансованої моделі, до відтворення якої повинні прагнути укладачі корпусів. Стефан Еверт, зокрема, уважає, що майбутнє корпусної лінгвістики полягає не в тому, щоб застосовувати все новіші прийоми аналізу даних або моделі deep learning, а в поєднанні людського пояснення та кількісного аналізу й візуалізації - злиття людини й машини (merging man and machine) у так званого Герменевтичного Kiбopza (Hermeneutic Cyborg) [10].

Представники когнітивної лінгвістики неодноразово зверталися до корпусного матеріалу та методології, і ця потреба все більше зростає. Відома сучасна когнітивістка Дагмар Дів'як [5] уважає, що когнітивна лінгвістика початку 2000-х зазнала зміни методологічної парадигми внаслідок розвитку так званих «базованих на вживанні» (usage-based) теорій мови (термін Р. Ленекера (1987) [11]), головним постулатом яких стало вивчення когнітивних репрезентацій, значення на основі аналізу вживання. Лінгвісти, які досліджують уживання, обгрунтовують важливість його вивчення на основі електронних корпусів [4]. Згідно з Джоан Байбі, евристичною мірою вживання $є$ частотність. Оскільки окремі мовні одиниці та їх послідовності повторюються частіше, аніж інші, можливо встановити особливості когнітивних репрезентацій, які залежать від того, наскільки їх використовували. Таким чином, у межах usage-based теорій частотність сприяє розумінню природи граматичної організації [12].

Джон Тейлор перший сформулював так звану прикладо-базовану (exemplar-based) теорію мовного знання та репрезентації на основі детального аналізу корпусних даних [13]. Згідно з Р. Ленекером, приклади (exemplars) групуються в «хмари прикладів» (exemplar clouds), які формують мовні категорії. Немає відмінності між «хмарою прикладів» i «схемою» в когнітивній лінгвістиці, «схема» - лише більш абстраговане та менш деталізоване узагальнення окремих патернів [14].

Існує низка досліджень, які намагаються поєднати когнітивно-лінгвістичну теорію та корпусну методологію. Перспективи розвитку корпусо-базованої когнітивної семантики помітив Д. Герертс [4, с. 286]. Праця Г. Шміда (1993) стала одною 3 перших грунтовних корпусо-базованих 
когнітивних семантичних розвідок [15]. Окремі дослідження стосуються аналізу колокацій i колігацій у вивченні полісемії [16; 17]. Результати таких досліджень указують на необхідність урахувати інформацію про лексико-граматичні конструкції, установлюючи зв'язки між різними смислами/значеннями багатозначного слова $[17$, c. 234].

Джон Ньюман у праці «Корпуси та когнітивна лінгвістика» (2011) твердить, що корпуси є природним джерелом матеріалу дослідження для когнітивних лінгвістів, оскільки більше ніж будь-яке інше джерело даних відображають реальне використання мови, що $є$ надзвичайно важливим у когнітивній лінгвістиці [18, с. 521]. Автор зазначає, що корпуси актуальні для вивчення всіх основних проблем когнітивної лінгвістики, зокрема концептуальної метафори, полісемії, синонімії, прототипів, аналізу конструкцій, і пропонує шляхи дослідження цих проблем за допомогою використання корпусів. Разом із тим Дж. Ньюман наголошує на необхідності вдосконалити будову та вміст сучасних корпусів так, щоб отримати всі види вживання даних, які необхідні для когнітивних лінгвістів $[18$, c. 522$]$.

Одним із популярних напрямів дослідження $\epsilon$ вивчення конщептуальної метафори із застосуванням корпусо-базованої методології. Корпусо-базовані usage-based методи значно розширюють межі досліджень концептуальної метафори, сприяють їх емпіричності. Рей Гіббс зазначає, що використання корпусів змушує дослідників чіткіше описувати «процедуру ідентифікації метафори в мові й у мисленні, що $є$ необхідним доповненням більш традиційного інтроспективного когнітивного лінгвістичного вивчення концептуальної метафори» (з інтерв'ю Р. Гіббса (2009), процитованого Дж. Ньюманом [18, с. 523]). Дж. Ньюман та Р. Гіббс також уважають, що більшої уваги заслуговує лексична та граматична поведінка, пов'язана з метафоричним уживанням. Когнітивне лінгвістичне дослідження є природним початковим етапом для корпусо-базованого підходу до аналізу метафори, оскільки дає змогу виявити метафоричне мапування від вихідного домену до цільового, що, у свою чергу, є стимулом дослідження вживання цих метафор, зокрема того, як часто вживаються певні метафоричні моделі порівняно з іншими; коли учасники дискурсу вживають певні метафори та визначають, які лексичні одиниці та конструкції є засобами вираження концептуальної метафори; які концептуальні моделі найбільш закріплені. Уживання певних метафор частіше, ніж інших, може вказувати на певний processing bias, що може відображати фундаментальні аспекти концептуалізації та культурно специфічні вподобання.
Загалом можна виділити два основні процедурні підходи до корпусного вивчення концептуальної метафори [19]. Перший підхід бере початок з вихідного домену (source domain) і полягає в пошуку слів, синонімічних рядів і семантичних полів у його межах, згодом ідентифікації метафоричних уживань і відповідних цільових доменів (target domains) вручну [20]. Альтернативний підхід до корпусного дослідження концептуальної метафори бере за основу цільовий домен: спочатку ведеться пошук абстрактних слів цільового домену з подальшою ідентифікацією тих, які вживаються в граматичних патернах разом 3 одиницями 3 різних семантичних доменів, які й будуть здебільшого вихідними доменами [19]. Так, А. Стефанович на основі метафоричних патернів у корпусах вивчає концепт ЩАСТЯ в американському варіанті англійської та німецькій мов [19].

Корпусо-базовані методи використовуються в дослідженні прототипів, центральних елементів категорій. Відповідно до Дж. Байбі, висока частотність токена (token frequency) у конструкції відіграє ключову роль у формуванні центральних категорій [21]; частотність типу (type frequency) i семантика також впливають на поведінку центрального елемента. М. Стаббс запропонував метод систематичного вивчення центральних уживань слова й асоціативної «лексико-граматичної рамки» [22, с. 84-96]. Метод передбачає аналіз колокатів для визначення патернів, які $€$ структурно та інформаційно вагомими. Існують і більш статистично складні методи, наприклад, колострукційний аналіз (collostructional analysis) [23], який передбачає систематичні корпусо-базовані процедури, що може використати когнітивна лінгвістика у визначенні прототипних уживань слів чи патернів. Основною перевагою цих методів $\epsilon$ те, що вони базуються на фактах реального вживання мови, доповнюючи інші методи, базовані на інтуїції чи експериментах. Течією, яка намагається поєднати когнітивну й корпусну лінгвістики, є граматика патернів Сюзан Ганстон і Джил Френсіс [24]. Робота бере за основу теорію фреймової семантики Філмора для опису патернів, отриманих у результаті корпусного аналізу.

Теорія лексичного праймінгу (lexical priming) також зближує когнітивну лінгвістику з корпусною. Поняття лексичного праймінгу, розроблене в когнітивній лінгвістиці, передбачає, що «в головному мозку є ментальний конкорданс кожного слова, яке він зустрічав... Цей ментальний конкорданс $є$ досяжний і може бути обробленим у такий же ж спосіб, як комп'ютерний конкорданс, так, що всі патерни, у тому числі колокації, готові до вживання〉 $[25$, с. 11]. Очевидно, такий ментальний конкорданс не $є$ тотожним корпусному 
конкордансу. Проте збалансована, правильна побудова корпусів та оптимізація анотації наближає корпусний конкорданс до ментального $[19$, c. 438$]$.

Окрім корпусо-базованої, розвивається й корпусо-керована когнітивна семантика (corpusdriven cognitive semantics), яку застосовують передусім для аналізу полісемії та синонімії. Розглядаючи квантитативні корпусо-керовані підходи до вивчення значення, Д. Глінн виокремлює підхід, що базується на характерних (observable) формальних патернах (аналіз колокацій), і підхід, який базується на патернах анотованих ознак уживання (feature analysis) [8, c. 545]. До центральних проблем когнітивної семантики належить дослідження лексичних семантичних відношень, передусім полісемії. За словами Дж. Ньюмана, вивчення специфіки відношень між смислами/значеннями слів як у випадку полісемії та основи/закономірностей таких відношень призводить до ширших дискусій про контексти, у яких певні слова чи смисли/значення слів виникають, особливості екстралінгвістичної реальності $[18$, с. 531]. Відповідно, контексти вживання, які можемо отримати 3 корпусу, значно розширюють дослідницькі можливості.

П. Генкс (1996) у дослідженні urge на основі аналізу колокації, колігації та тріангуляції (sense triangulation, співвідношення колокатів у різних ролях у реченні) запропонував так звані «поведінкові профілі» (Behavioral Profiles), або сукупність патернів слова, які визначають його семантику [26, с. 77]. Як правило, когнітивні семантичні дослідження традиційно базуються на деконтекстуалізованому матеріалі, зібрання/вибірка й аналіз якого здійснюються за допомогою інтроспекції. Відповідно, результати дослідження можуть бути емпірично проблематичними, не всі визначені смисли/значення підтверджуються реальними даними [27]. Разом із тим використання інтроспекції як способу збору матеріалу дослідження та інтуїції як основного аналітичного методу перешкоджає розробці точної та об'єктивної методології. Натомість корпусобазовані або комп'ютернолінгвістичні дослідження грунтуються на великій сукупності даних, проте їх дослідження може видаватися менш цікавим із лінгвістичної точки зору, оскільки корпусобазовані дослідження нерідко обмежуються аналізом слів, які мають кілька різних значень, або невеликої кількості груп семантично подібних слів, зазвичай зосереджуються на проблемах, що мало цікавлять теоретичну лінгвістику, на зразок семантичної просодії, базуються на доступній незначній вибірці даних, ці дані можуть бути помилковими чи викривленими через (напів)автоматизовані засоби опрацювання [27].
Підхід із застосуванням поведінкових профілів, який, на думку Д. Дів'як та С. Грайса, поєднує все найкраще 3 когнітивної та корпусної лінгвістичної традицій, дає змогу отримати вагомі для когнітивної лінгвістики результати й може застосовуватися в зіставних дослідженнях [3]. Ключові поняття підходу поведінкових профілів грунтуються на паралелізмі між дистрибутивним i функційним планами. Спочатку всі вживання леми видобуваються з корпусу, після цього здійснюється (здебільшого) ручний аналіз морфо-синтаксичних, синтаксичних i семантичних особливостей досліджуваного слова, його колокатів і речень, у яких воно вживається. Ураховується комплекс елементів, які вживаються зі словом у межах речення в реальному усному чи писемному мовленні. Таким чином, будується максимально всебічний поведінковий профіль досліджуваних лексичних одиниць, який характеризується детальнішою анотацією та оптимальнішою статистичною оцінкою даних. Семантичний опис повністю базується на отриманих даних, тобто $є$ керований даними (data-driven), потреба в можливій особистій інтерпретації дослідника відтерміновується до останнього етапу аналізу або повністю відпадає. Такий метод забезпечує об'єктивну основу семантичного аналізу полісемічних i синонімічних одиниць. «Об'єктивна» означає, що навіть якщо класифікацію даних можна вважати суб'єктивною до певної міри, обсяг даних дослідження визначено об'єктивно (використовується довільна вибірка конкордансу), анотація даних $\epsilon$ чіткою та логічною, здійснено аналіз даних за допомогою статистичних методів. Інтуїція використовується на етапі роз'яснення результатів.

3 огляду на те що полісемія так само, як і синонімія, мають градуальні характеристики, Дж. Ньюман уважає, що дослідження цих типів семантичних відношень вимагає застосування методів, які дадуть змогу виявити різні ступені відношень уживань слів або різні ступені подібності слів у вживанні $[18$, с. 538]. Окрім поведінкових профілів, застосовують також аналіз відповідностей (correspondence analysis) і кластеринг (clustering analysis). Ці корпусо-базовані методи, ураховуючи в процесі аналізу контекстуальні дані, які можна видобути 3 корпусу, вдало підходять для виявлення градуальності, пов'язаної з полісемією та синонімією. Хоча це вимагає значних зусиль на кодування властивостей релевантних чинників, групування даних (data frames), що є основою для статистичного аналізу, проте в результаті отримуємо яскраву візуалізацію та концептуалізацію $[18$, c. 538$]$.

Перспективним Дж. Ньюман уважає застосування мультимодальних корпусів, які інтегрують відео й аудіовиміри. У працях із когнітивної 
лінгвістики зустрічаємо думки про переваги так званого «ситуативного» (situated) мовного фокусу дослідження. В. Еванс та М. Грін уважають ситуативні випадки вживання мови базовим, «сирим» досвідом, із якого мовці будують ментальну граматику [28, с. 478]. Із цього випливає, що вивчення ситуативних випадків уживання мови $є$ фундаментальним аспектом мовного досвіду мовців, а не якимось периферійним, випадковим явищем. Погоджуючись із цим твердженням, Дж. Ньюман уважає, що треба розширити традиційні види даних, які представлені в корпусах на зразок BNC i COCA [18, с. 538]. Потрібно досліджувати дані 3 усіх каналів комунікації, тобто дані, у яких жести рук, погляд, швидкість і манера руху тіла, вираз обличчя, постава тощо інтегровані в матеріал дослідження, і ці дані мають міститися в корпусах $[29$, c. $82-83]$.

Проте з часом, після ейфорії щодо можливості обробки великої кількості даних, застосування статистичних параметрів, у когнітивних лінгвістів з'являються й сумніви стосовно того, чи ідентифіковані патерни вживання реальні, нереально існують як дані, а реально існують у мозку мовців [7]. У статті "Working toward a synthesis" (2016) P. Ленекер твердить, що, тоді як корпусні дані необхідні для багатьох цілей, виявлені інтроспективні дані не менш важливі, а важливість квантитативних методів не применшує центральної ролі структурного аналізу й опису, які однаково претендують на те, аби бути емпіричними [30].

Висновки й перспективи подальших розробок. Для сучасної когнітивної лінгвістики як напряму лінгвістики, який зазнав зміни методологічної парадигми та базується на реальному вживанні мови, корпуси $є$ не лише ще одним типом даних, які треба взяти до уваги разом 3 іншими методами дослідження, такими як інтуїція, експериментальні методи тощо. Більше ніж будь-які інші типи мовних даних, корпуси репрезентують уживання мови, тому $є$ найважливішим видом даних, на які сучасна когнітивна лінгвістика може покладатися.

Розглянуті напрями, тенденції та конкретні приклади досліджень, які базувалися на синергії когнітивної теорії та корпусної методології, свідчать про результативність і перспективу такого підходу. Разом із тим важливою $є$ розробка нових методів опрацювання даних. Сьогодні корпуси містять величезну кількість даних, які неможливо проаналізувати вручну. Виникає необхідність не лише застосування та оптимізації методів автоматизованого видобування й аналізу даних, статистичного аналізу, а й покращення якості інтроспекції. Збір мультимодальних даних, урахування відео та аудіо, розвиток стандартів анотування й доступу до даних є сьогодні одними 3 першочергових завдань. Таким чином, переосмислення мови як діяльності, яка реалізується через ситуативні випадки вживання мови й досліджується через мультимодальні корпуси, $є$ вельми перспективним напрямом розвитку когнітивної лінгвістики.

\section{ЛIТЕРАТУРА}

1. Gries S. Th., Stefanowitsch A. Corpora in Cognitive Linguistics. Berlin, New York : De Gruyter Mouton, 2008. 352 p.

2. Arppe, A., Gilquin G., Glynn D., Hilpert M., Zeschel A. Cognitive Corpus Linguistics: Five points of debate on current theory and methodology. Corpora. 2010. Vol. 5 (1). P. 1-27.

3. Lewandowska-Tomaszczyk B., Dziwirek K. Studies in Cognitive Corpus Linguistics. Bern, Switzerland : Peter Lang D., 2009. 405 p.

4. Geeraerts D. Theories of lexical semantics. Oxford : Oxford University Press. Chicago, 2010. 317 p.

5. Попова З.Д., Стернин И.А. Очерки по когнитивной лингвистике. Воронеж : Истоки, 2001. $191 \mathrm{c.}$

6. McEnery T., Hardie A. Corpus linguistics. Cambridge : Cambridge University Press, 2012. $294 \mathrm{p}$.

7. The Sinclair Lecture 2021: Professor Dagmar Divjak. URL: https://www.birmingham.ac.uk/ schools/edacs/departments/englishlanguage/ events/2021/sinclair-lecture-2021.aspx (Accessed: 10 August 2021).

8. Glynn D., Robinson J. Corpus Methods for Semantics: Quantitative studies in polysemy and synonymy. John Benjamins, 2014. 545 p.

9. Paquot M., Stefan Th. Gries S. Th. A practical handbook of corpus linguistics. Berlin \& New York : Springer, 2020. $688 \mathrm{p}$.

10. The Sinclair Lecture 2018: Professor Stefan Evert. URL: https://www.birmingham.ac.uk/ research/activity/corpus/news/2018/sinclairlecture-2018.aspx (Accessed: 10 August 2021).

11. Langacker R.W. Foundation of Cognitive Grammar (in 2 vol.). Stanford : Stanford University Press, 1987.

12. Bybee J.L. Usage-based Theory and Exemplar Representations of Constructions. The Oxford Handbook of Construction Grammar / T. Hoffmann, G. Trousdale (ed.). Oxford : Oxford University Press, 2013. P. 49-69.

13. Taylor J.R. The Mental Corpus. How Language is Represented in the Mind. Oxford : Oxford University Press, 2012. 384 p.

14. Langacker R. W. Entrenchment in Cognitive Grammar. Entrenchment and the Psychology of Language Learning: How We Reorganize and Adapt Linguistic Knowledge / H.-J. Schmid (ed.). Berlin : De Gruyter Mouton, 2017. P. 39-56. 
15. Schmid H.-J. Cottage und Co., idea, start vs. begin: Die Kategorisierung als Grundprinzip einer differenzierten Bedeutungsbeschreibung. Linguistische Arbeiten, Band, 1993.

16. Kishner J.M., Gibbs R.W. Jr. How just gets its meanings: Polysemy and context in psychological semantics. Language and Speech.1996. Vol. 39 (1). P. 19-36.

17. Gibbs R.W.Jr., Matlock T. Psycholinguistic perspectives on polysemy. Polysemy in Cognitive Linguistics / H. Cuyckens, B. Zawada (eds.). Amsterdam, Philadelphia : John Benjamins, 2001. P. 213-39.

18. Newman J. Corpora and cognitive linguistics. Revista Brasileira de Linguística Aplicada [online]. 2011. Vol. 11. № 2. P. 521-559. URL: https://doi.org/10.1590/S1984-639820 11000200010 (Accessed: 10 August 2021).

19. Stefanowitsch A. Corpus Linguistics. A Guide to the methodology. Berlin : Language Scince Press, 2020. $490 \mathrm{p}$.

20. Deignan A. Corpus-based research into metaphor. Researching and applying metaphor / G. Low, L. Cameron (eds.). Cambridge : Cambridge University Press, 1999. P. 177-199.

21. Bybee J. Categorization and the distribution of constructions in corpora. Language, Usage and Cognition. Cambridge : Cambridge University Press, 2010. P. 76-104.

22. Stubbs M. Words and phrases: corpus studies of lexical semantics. Oxford : Blackwell, 2001. $288 \mathrm{p}$.

23. Stefanowitsch A., Gries St. Th. Collostructions: investigating the interaction between words and constructions. International Journal of Corpus Linguistics. 2003. Vol. 8. № 2, P. 209-243.

24. Hunston S., Francis G. Pattern grammar: A corpus-driven approach to the lexical grammar of English. Amsterdam \& Philadelphia : John Benjamins, 2000. 289 p.

25. Hoey M. Lexical priming: A new theory of words and language. London \& New York : Routledge, 2005. $220 \mathrm{p}$.

26. Hanks P. Contextual dependency and lexical sets. International Journal of Corpus Linguistics. 1996. Vol. 1 (1). P. 75-98.

27. Gries S., Divjak D. Quantitative approaches in usage-based Cognitive Semantics: Myths, erroneous assumptions, and a proposal. Quantitative Methods in Cognitive Semantics: Corpus-Driven Approaches / D. Glynn, K. Fischer (ed.). Berlin, New York : De Gruyter Mouton, 2010. P. 331-354.

28. Evans V., Green M. Cognitive linguistics: an introduction. Edinburgh : Edinburgh University Press, 2006. 830 p.
29. Wichmann A. Corpora and spoken discourse. Corpus linguistics 25 years on / R. Facchinetti (ed.). Amsterdam and New York : Rodopi, 2007. P. 82-83.

30. Langacker R.W. Working Toward a Synthesis. Cognitive Linguistics. 2016. Vol. 27 (4). P. 465-477.

\section{REFERENCES}

1. Gries, S. \& Stefanowitsch, A. (2008). Corpora in Cognitive Linguistics. Berlin, New York: De Gruyter Mouton.

2. Arppe, A. et. al. (2010). Cognitive Corpus Linguistics: Five points of debate on current theory and methodology. Corpora 5 (1): 1-27.

3. Lewandowska-Tomaszczyk, B. \& Dziwirek, K. (Eds.) (2009). Studies in Cognitive Corpus Linguistics. P. Lang, 2009.

4. Geeraerts, D. (2010). Theories of lexical semantics. Oxford: Oxford University Press. Chicago.

5. Popova, Z. D. \& Sternin, I. A. (2001). Essays in Cognitive Linguistics [Ocherki po kognitivnoy lingvistike]. Voronezh: Istoky.

6. McEnery, T. \& Hardie, A. (2012). Corpus linguistics. Cambridge: Cambridge University Press.

7. The Sinclair Lecture 2021: Professor Dagmar Divjak. URL: https://www.birmingham.ac.uk/ schools/edacs/departments/englishlanguage/ events/2021/sinclair-lecture-2021.aspx.

8. Glynn, D. \& Robinson, J. (2014). Corpus Methods for Semantics: Quantitative studies in polysemy and synonymy. John Benjamins.

9. Paquot, M. \& Gries, St. Th. (Eds.). (2020). A practical handbook of corpus linguistics. Berlin \& New York: Springer.

10. The Sinclair Lecture 2018: Professor Stefan Evert. URL: https://www.birmingham.ac.uk/ research/activity/corpus/news/2018/sinclairlecture-2018.aspx.

11. Langacker, R. W. (1987). Foundation of Cognitive Grammar (in 2 vol.). Stanford: Stanford University Press.

12. Bybee, J. L. (2013). Usage-based theory and exemplar representations of constructions. In T. Hoffmann \& G. Trousdale (Eds.), The Oxford handbook of construction grammar (pp. 49-69). New York : Oxford University Press.

13. Taylor, J. R. (2012). The Mental Corpus. How Language is Represented in the Mind. Oxford: Oxford University Press.

14. Langacker, R. W. (2017). Entrenchment in cognitive grammar. In H.-J. Schmid (Ed.), Entrenchment and the psychology of language learning: How we reorganize and adapt linguistic knowledge (pp. 39-56). American Psychological Association; De Gruyter Mouton. 
15. Schmid, H.-J. (1993). Cottage und Co., idea, start vs. begin: Die Kategorisierung als Grundprinzip einer differenzierten Bedeutungsbeschreibung. Linguistische Arbeiten, 290.

16. Kishner, J. M. \& Gibbs, R. W. Jr. (1996). How just gets its meanings: Polysemy and context in psychological semantics. Language and Speech 39(1): 19-36.

17. Gibbs, R. W. Jr. \& Matlock, T. (2001). Psycholinguistic perspectives on polysemy. In Cuyckens, H. \& B. Zawada (Eds.). Polysemy in Cognitive Linguistics. Amsterdam (pp. 213-239). Philadelphia: John Benjamins.

18. Newman, J. Corpora and cognitive linguistics. Revista Brasileira de Linguística Aplicada [online]. 2011, v. 11, n. 2 [Accessed 10 August 2021], pp. 521-559. URL: https:// doi.org/10.1590/S1984-63982011000200010.

19. Stefanowitsch, A. (2020). Corpus Linguistics. $A$ Guide to the methodology. Berlin: Language Scince Press.

20. Deignan, A. (1999). Corpus-based research into metaphor. In Graham Low \& Lynne Cameron (Eds.), Researching and applying metaphor (pp. 177-199). Cambridge: Cambridge University Press.

21. Bybee, J. (2010). Categorization and the distribution of constructions in corpora. In Language, Usage and Cognition (pp. 76-104). Cambridge : Cambridge University Press.

22. Stubbs, M. (2001). Words and phrases: corpus studies of lexical semantics. Oxford: Blackwell.
23. Stefanowitsch, A. \& Gries, St. Th. (2003). Collostructions: investigating the interaction between words and constructions. International Journal of Corpus Linguistics, 8(2), 209-243.

24. Hunston, S. \& Francis, G. (2000). Pattern grammar: A corpus-driven approach to the lexical grammar of English (Studies in corpus linguistics 4). Amsterdam \& Philadelphia: John Benjamins.

25. Hoey, M. (2005). Lexical priming: A new theory of words and language. London \& New York: Routledge.

26. Hanks, P. (1996). Contextual dependency and lexical sets. International Journal of Corpus Linguistics 1(1): 75-98.

27. Gries, S. \& Divjak, D. (2010). Quantitative approaches in usage-based Cognitive Semantics: Myths, erroneous assumptions, and a proposal. In D. Glynn \& K. Fischer (Eds.), Quantitative Methods in Cognitive Semantics: Corpus-Driven Approaches (pp. 331-354). Berlin, New York : De Gruyter Mouton.

28. Evans, V. \& Green, M. (2006). Cognitive linguistics: an introduction. Edinburgh: Edinburgh University Press.

29. Wichmann, A. (2007). Corpora and spoken discourse. In Facchinetti, R. (Ed.), Corpus linguistics 25 years on (pp. 82-83). Amsterdam and New York : Rodopi.

30. Langacker, R. W. (2016). Working Toward a Synthesis. Cognitive Linguistics 27. 465-477. 